ORIGINAL ARTICLE

\title{
Serum markers of collagen metabolism: construction workers compared to sedentary workers
}

\author{
J I Kuiper, J H A M Verbeek, V Everts, J P Straub, M H W Frings-Dresen
}



Occup Environ Med 2005;62:363-367. doi: 10.1136/oem.2004.016998

Additional material is available on the OEM website at http://www. occenvmed.com/ supplemental

See end of article for authors' affiliations .....................

Correspondence to: Dr J H A M Verbeek, Coronel Institute for Occupational and Environmental Health, Academic Medical Center/University of Amsterdam, PO Box $22700,1100 \mathrm{DE}$

Amsterdam, Netherlands; j.h.verbeek@amc.uva.nl

Accepted

17 December 2004

\begin{abstract}
Background: Evaluation of causal relations between physical load and musculoskeletal disorders is hampered by the lack of knowledge as to the biological relevance of different loading parameters and the large variability between individuals. As indicators of molecular changes in the extracellular matrices of structures of the musculoskeletal system, biomarkers of collagen metabolism may provide important information on biological effects of physical load. The carboxyterminal propeptide of type I collagen (PICP) is a serum marker of synthesis and the carboxyterminal telopeptide region of type I collagen (CTx) reflects degradation of type I collagen.

Aims: To explore the feasibility of biomarkers of type I collagen metabolism as measures of the effects of physical load at tissue level.

Methods: Serum concentrations of PICP and CTx were assessed in a group of male construction workers involved in heavy manual materials handling $(n=47)$ and in a group of male sedentary workers $(n=49)$. Results: Serum concentrations of both PICP and CTx seemed to be related to heavy physical work. The ratio $\mathrm{PICP} / \mathrm{CTx}$, illustrative of the effective metabolic changes, did not differ between the two groups.

Conclusions: The higher turnover rate but similar effective synthesis may be indicative of an increased type I collagen content in the connective tissues as a result of adaptive remodelling in response to years of exposure to physical load. Further validation of these biomarkers is required with respect to dose-response relations and temporal associations between exposure to back load and biomarker concentrations.
\end{abstract}

$\mathrm{E}$ pidemiological studies have identified associations between physical demands at work (manual materials handling, bending and twisting, and whole body vibration) and musculoskeletal disorders, especially back disorders. ${ }^{1-5}$ However, understanding of the biological relevance of different loading parameters and why some people are at greater risk of developing musculoskeletal disorders is still deficient because adequate and relevant measures of exposure as well as outcome are lacking. Although methods and strategies to accurately assess external exposure as well as biomechanical models to estimate the response of the tissues to these exposures have been developed, ${ }^{67}$ very little is known about biologically effective doses and early biological effects in vivo. As indicators of changes at a tissue or molecular level in the structures of the musculoskeletal system, biomarkers may provide important complementary information. Unfortunately, there are no validated biomarkers to assess the effects of physical load available yet. Following the hypothesis that physical load causes responses in the musculoskeletal structures leading to changes in metabolism of the extracellular matrix (ECM) of connective tissues, ${ }^{8}$ matrix metabolites could provide potential biomarkers of the biological effects of physical load on these structures. In connective tissues the extracellular matrix is responsible for the overall structural integrity of the tissue. When the level of load is slowly increased the result may be an adaptive remodelling of the tissues. However, if the increase in load is sudden or large, the cells may not adapt quickly enough and damage may result. ${ }^{9}$ Since type I collagen is one of the main constituents of the ECM of most connective tissues, including bony structures, joints, and ligaments, tissue responses can be monitored by assessment of the kinetics of type I collagen synthesis and degradation. Validated biomarkers have been developed for analysis of type I collagen turnover: synthesis can be assessed by analysis of serum concentrations of carboxyterminal propeptide of type I collagen (PICP), whereas breakdown can be detected by analysis of the carboxyterminal telopeptide region of type I collagen $(\mathrm{CTx}) .{ }^{10}$ The ratio between PICP and CTx provides an estimate of type I collagen metabolism as a dynamic process of synchronously occurring anabolic and catabolic effects.

To explore these biomarkers of type I collagen metabolism as measures of physical load at tissue level, the association between the biomarkers and occupational exposure to physical load was investigated. The objective of the study was to determine whether serum concentrations of PICP and CTX, and the ratio PICP/CTX in males who have been exposed to physical load for years differ from those in a non-exposed reference group.

\section{METHODS}

In a cross-sectional study the serum concentrations of PICP and CTx were assessed as well as data on physical load from men working in occupations involving heavy manual materials handling and from men working in sedentary occupations. The study was approved by the Ethics

Abbreviations: $\mathrm{BMl}$, body mass index; $\mathrm{CTx}$, carboxyłerminal telopeptide region of type I collagen; ECM, extracellular matrix; $\mathrm{PICP}$, carboxyterminal propeptide of type I collagen 


\section{Main messages}

- PICP and CTx indicated a higher collagen type I turnover, but a similar effective synthesis, in men that have been exposed to heavy manual materials handling for years when compared to men in sedentary occupations.

- These results may reflect adaptive remodelling; however, the effects of recent and cumulative exposure in the past cannot be separated.

- Further validation of PICP and CTx is needed with respect to dose-response relations and temporal associations between exposure to physical load and biomarker concentrations.

Committee of the Academic Medical Center/University of Amsterdam, Netherlands.

\section{Subjects}

The study population consisted of two groups of male workers aged between 30 and 40 years: a group of construction workers engaged in heavy physical work $(n=47)$ and a group of sedentary workers $(n=49)$. The group of construction workers consisted of men with different occupations within the construction branch. The inclusion criteria were: for at least $50 \%$ of their working time they had to be engaged in manual materials handling, such as lifting, carrying, pushing, or pulling of heavy loads; and they had to have been engaged in physically demanding work for about 10 years or more. Subjects were asked to volunteer when they visited the Occupational Health Service (ArboUnie Amsterdam) for a periodic occupational health examination. Subjects for the sedentary group were recruited from three different populations: office workers from insurance companies who visited the Occupational Health Service (ArboUnie Amsterdam) for a periodic occupational health examination; office workers in the Academic Medical Center; and occupational physicians. In the sedentary group men were only included if they had not practiced a profession involving heavy physical work during the previous 10 years. Subjects were fully informed about the procedures and completed an informed consent form. To prevent confounding, we restricted our sample to male workers because there are differences in normal values of biomarkers between men and women, and the proportion of male workers in construction work is high compared to sedentary work.

Based on data from Langberg et al, we assumed a possible difference of $10 \mathrm{ng} / \mathrm{l}$ in PICP concentration as relevant and took the SD of $17 \mathrm{ng} / \mathrm{l}$ from their study. ${ }^{11}$ To be able to detect such a difference with $\alpha=0.05$ and $\beta=0.80$ we needed 46 subjects in both experimental and reference groups. ${ }^{12}$

All subjects filled out a questionnaire concerning personal characteristics such as age, height, and weight, as well as the occurrence of low back pain during the previous 12 months as the main indicator of musculoskeletal problems. Furthermore, they were asked about medication, and whether they suffered or had suffered in the previous year from musculoskeletal traumas, joint diseases, liver or kidney diseases, and blood or metabolic diseases (such as diabetes). Subjects who reported suffering/having suffered from any of these diseases or traumas were not admitted to the study because of the potentially confounding effect on the serum concentrations of the collagen markers. Table 1 presents the characteristics of the study population.

\section{Policy implications}

- Serum markers of collagen type I metabolism may be an integral marker of physical load.

- The availability of commercial kits to measure serum markers of collagen makes it possible to easily measure the effects of physical load.

- Further validation of the use of serum markers for this purpose is needed before it is feasible to use these markers in practice.

\section{Data collection}

Blood samples were collected by means of venipuncture in the anticubital vein. After coagulation the blood was centrifuged and serum stored at $-20^{\circ} \mathrm{C}$ until analysed.

To explore the contrast in exposure to physical load, subjects filled out parts of the Loquest questionnaire ${ }^{13}$ to assess work related physical exposures (lifting or carrying loads $(>5 \mathrm{~kg}$ ) or heavy loads $(>25 \mathrm{~kg})$, pushing or pulling loads $(>50 \mathrm{~kg})$ or heavy loads $(>200 \mathrm{~kg})$, bending and/or twisting at work and vehicle driving) and leisure time physical activities (physically demanding household activities, do-it-yourself jobs, and sport). The answers were assessed on a four point scale (seldom or never, sometimes, quite often, very often). We used the combined frequencies of those that reported being engaged often or regularly in a certain activity, compared to those that did this seldom or never. The questionnaire has been validated based on a factor analysis and divergent validity. ${ }^{14} 15$

\section{Analyses of PICP and CTx}

The serum concentrations of PICP were measured by the Prolagen-C sandwich ELISA (Metra Biosystems, Mountain View, USA). CTx serum concentrations were analysed using the serum CrossLaps One Step ELISA (OSTEOMETER, Herlev, Denmark). Samples from both occupational groups were analysed simultaneously, randomly divided over nine kits of each of the assays. All samples were analysed in duplicate. The intra-assay precision (coefficient of variation) was $3.8 \%$ for PICP and $4.8 \%$ for CTx; inter-assay coefficients of variation were $9.9 \%$ and $11.9 \%$, respectively. Normal values for PICP have been reported as $76-163 \mathrm{ng} / \mathrm{ml}$ for males. For CTx these values are $0.04-0.93 \mathrm{ng} / \mathrm{ml}$ for males. ${ }^{16}$

\section{Statistical analysis}

Serum concentrations of PICP and CTx were correlated. To test whether collagen type I metabolism differed between the two occupational groups, an analysis of variance with repeated measures was performed with serum PICP and CTX as dependent variables, and occupational group as the independent variable. Because body mass index (BMI) has been reported to be related to biomarkers of collagen metabolism, BMI was included as a co-variable to control for potential confounding. ${ }^{17}$ Differences in the balance between serum PICP and CTx was tested using an analysis of variance with the PICP/CTx ratio as the dependent variable, group as the independent variable, and body mass index as co-variable. Differences were accepted as statistically significant at $\mathrm{p}<0.05$. All statistical analyses were performed with the Statistical Package for Social Sciences (SPSS for Windows, version 9.0).

\section{RESULTS}

\section{Exposure}

The results of the questionnaire on engagement in the different occupational activities and postures confirmed the 
Table 1 Characteristics of the study population

\begin{tabular}{|c|c|c|c|c|}
\hline \multirow[b]{3}{*}{ Characteristics } & \multirow{2}{*}{\multicolumn{2}{|c|}{$\begin{array}{l}\text { Construction workers } \\
(n=47)\end{array}$}} & \multirow{2}{*}{\multicolumn{2}{|c|}{$\begin{array}{l}\text { Sedentary workers } \\
(n=49)\end{array}$}} \\
\hline & & & & \\
\hline & Mean & (SD) & Mean & (SD) \\
\hline $\begin{array}{l}\text { Age (y) } \\
\text { Height }(\mathrm{m}) \\
\text { Weight }(\mathrm{kg}) \\
\text { BMI }\left(\mathrm{kg} / \mathrm{m}^{2}\right)\end{array}$ & $\begin{array}{l}34.5 \\
1.79 \\
82.2 \\
25.6\end{array}$ & $\begin{array}{l}(4.0) \\
(0.07) \\
(12.0) \\
(3.1)\end{array}$ & $\begin{array}{l}35.5 \\
1.81 \\
81.0 \\
24.5\end{array}$ & $\begin{array}{l}(3.0) \\
(0.06) \\
(10.1) \\
(2.6)\end{array}$ \\
\hline Low back pain & Frequency & $(\%)$ & Frequency & $(\%)$ \\
\hline Past 12 months & 34 & (72.3) & 30 & (61.2) \\
\hline
\end{tabular}

contrast in exposure between the two groups (see Appendix, available on the $O E M$ website at http://www.occenvmed. com/supplemental). The construction workers were more engaged in manual materials handling activities such as lifting, carrying, pushing and pulling. The two groups did not differ with respect to driving during work and engagement in physically demanding leisure activities. All subjects worked full time.

\section{Biomarkers of collagen type I metabolism}

Figure 1 shows the mean serum concentrations of PICP, CTx, and the PICP/CTx ratio for each occupational group. Because of deviation from the Normal distribution we transformed the values of PICP, CTx, and their ratio to their natural logarithms. The combined analyses of between-group differences of PICP and CTx showed that, when corrected for BMI, the serum concentrations of these biomarkers were almost significantly related to working in the construction industry $(F(1,90)=3.89, p=0.052)$. The balance between synthesis and degradation, as indicated by the PICP/CTX ratio, was equal for the two groups $(\mathrm{F}(1,90)=1.16, \mathrm{p}=0.284)$. In both groups large inter-individual variations were found for the concentrations of PICP and CTx as well as for the PICP/CTx ratio.

\section{DISCUSSION}

This study showed a positive, marginally significant, association between the serum concentrations of PICP and CTx and occupational physical load. The biomarker concentrations reflect a higher rate of collagen type I turnover in men exposed to heavy physical load when compared to men in sedentary occupations. This is in accordance with the theory that connective tissues respond to changes in physical load. Micro fractures and altered mechanical environment resulting from long term physical loading may lead to both increased degradation of matrix components and increased synthesis to replace those lost. As indicated by the comparable PICP/CTx ratio in the two groups, a higher degradation rate in the construction workers was balanced by a higher synthesis rate. These results suggest that the group of construction workers in this study consisted of men whose connective tissues had been adapted to the high levels of physical load. This might indicate that strong workers and workers who are capable of adapting have a higher chance to survive in physically demanding occupations. Such adaptive remodelling has been illustrated by findings of dense vertebrae in weight lifters, and stronger discs and vertebrae in physically active people. ${ }^{9}$ It is expected that if the adaptive response cannot keep pace with the loading, either because of sudden increase of the loading or because of state of the tissue, degradation of collagen and structural disruption of the ECM is likely to occur.'
Although an altered molecular composition in response to years of exposure is a plausible explanation, current exposure may also have affected the biomarker concentrations. Blood concentrations of type I collagen metabolic markers reflect the actual status of type I collagen metabolism, and collagen type I synthesis has been reported to be accelerated in response to heavy physical exercise (for example, running a marathon), reaching a peak after about three days and returning to baseline levels five days after completion of the exercise. ${ }^{11}$ Because of the cross-sectional design of the present study, it is not possible to separate the effects of recent exposure or cumulative effects of past exposure. Therefore, assessment of exposure response relations and temporal correlations between exposure and biomarker concentrations in longitudinal studies is an important issue for further exploration of these biomarkers. In addition, future studies should consider evaluating relations with various other kinds of physical activity such as physical conditioning and endurance.

In this study, considerable inter-individual variations in serum concentrations of both PICP and CTx, as well as the PICP/CTX ratio existed. None of the other variables that we measured, such as back pain prevalence could explain the inter-individual variation. The mean concentrations of PICP, CTx, and their ratio were not statistically significantly different between those with and those without back pain. Although the exact causes of variation are not completely understood, it is conceivable that these variations are indicative of individual differences in the condition and response of connective tissues to physical load. Since the study population was homogeneous with respect to gender, age, and body mass, these differences may be due to hereditary factors. Biomarkers as well as the association between exposure and biomarkers may be influenced by genetic make-up through differences in metabolism and susceptibility. ${ }^{18}$ Furthermore, there is growing evidence for genetically determined susceptibility for degenerative disorders of the musculoskeletal system such as disc degeneration. ${ }^{19}$

Unfortunately, the relative contributions of site specific connective tissues in the human body cannot be distinguished from serum concentrations. Animal studies reported increased collagen synthesis in intervertebral discs following exposure to compressive forces, ${ }^{20-22}$ but the contribution of other connective tissues in other parts of the body to the serum concentrations of PICP and CTx cannot be ruled out. Type I collagen is the major collagen type of the human body; it is found in all connective tissues, and particularly in those that are subjected to tension and compression like tendon, bone, and the annulus fibrosus of intervertebral discs. PICP and CTx have also been used to monitor the effects of weight bearing physical exercise on bone metabolism and tendons. ${ }^{11}{ }^{23-30}$ However, very few studies actually correlated the 

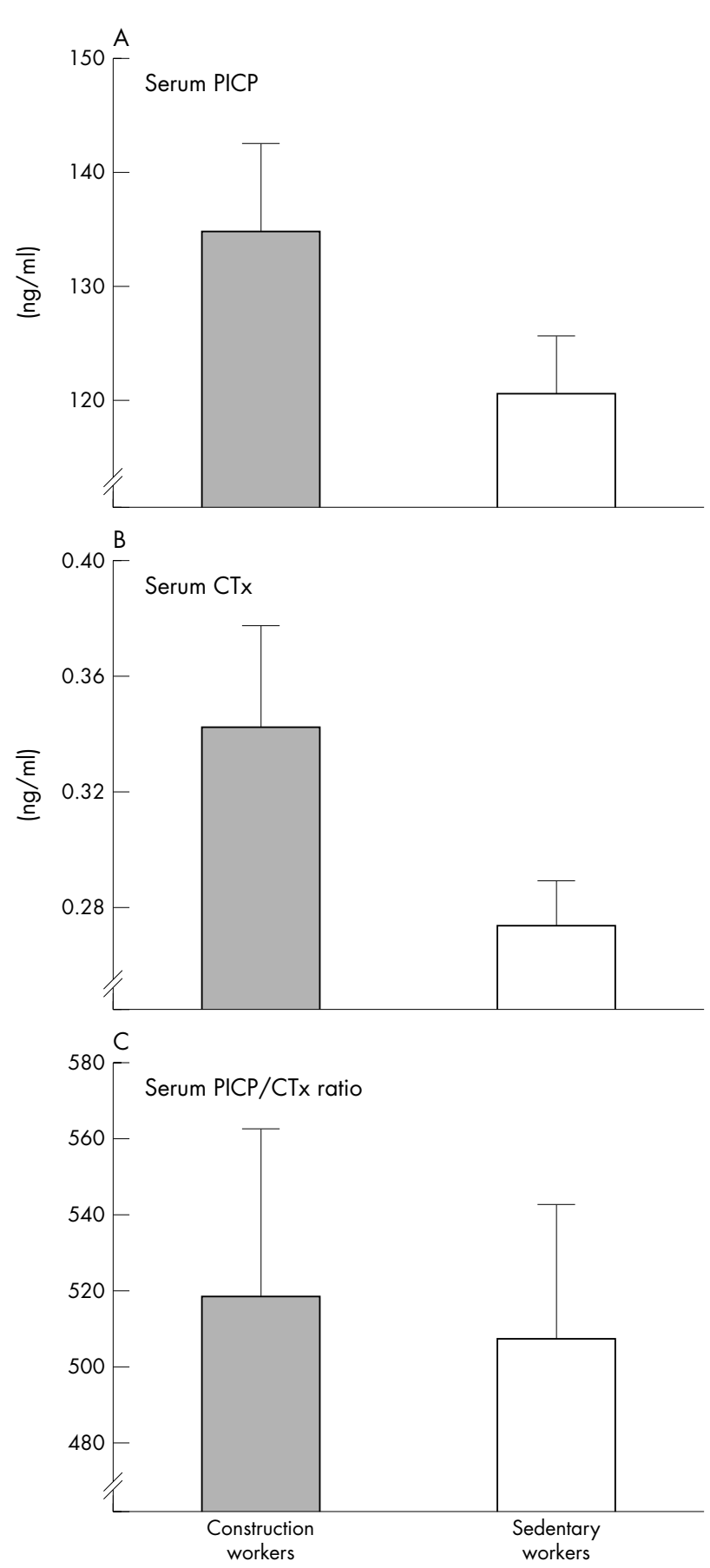

Figure 1 Mean (+1 SEM) serum concentrations of PICP (A), CTx (B), and the ratio PICP/CTx (C) in the construction workers $(n=47)$ and the sedentary workers $(n=49)$.

PICP or CTx concentrations to molecular changes in the structures they claimed to measure. Associations have only been reported with bone mineral density or bone scans ${ }^{31-33}$ and collagen concentrations in tendons measured by microdialysis. ${ }^{30}$ Because of this non-specificity, an issue for further validation of PICP and CTx is to combine assessment of these biomarkers with imaging data of relevant structures.

\section{Conclusions}

Serum concentrations of PICP and CTx indicated a higher turnover rate but similar effective synthesis in men exposed to heavy occupational physical load when compared to men in sedentary occupations. This may be indicative of an increased type I collagen content in the connective tissues as a result of adaptive remodelling in response to years of exposure to physical load. However, further validation of these biomarkers is required with respect to dose-response relations and temporal associations between exposure to physical load and biomarker concentrations. Furthermore, to be able to draw conclusions on biological relevance of the biomarker concentrations, associations with structural changes in the musculoskeletal system need to be established.

\section{ACKNOWLEDGEMENTS}

We thank Dr A van der Beek for his comments on the text and his contribution to the statistical analyses, and S Kuiper for performing the laboratory analyses. Furthermore, we owe many thanks to ArboUnie Amsterdam for their efforts in recruiting participants, and to all the men who voluntarily participated in the study.

\section{Authors' affiliations}

J I Kuiper, J H A M Verbeek, J P Straub, M H W Frings-Dresen, Coronel Institute for Occupational and Environmental Health, Academic Medical Center/University of Amsterdam, Netherlands

V Everts, Department of Cell Biology and Histology, Academic Medical Center/University of Amsterdam, The Netherlands and Department of Periodontology, Academic Center for Dentistry Amsterdam, University of Amsterdam, Netherlands

Competing interests: none declared

\section{REFERENCES}

1 Bernard BP. Musculoskeletal disorders and workplace factors. A critical review of epidemiologic evidence for work-related musculoskeletal disorders of the neck, upper extremity, and low back. Cincinnati, $\mathrm{OH}$ : National Institute for Occupational Safety and Health, US Department of Health and Human Services, 1997.

2 Burdorf A, Sorock G. Positive and negative evidence of risk factors for back disorders. Scand J Work Environ Health 1997;23:243-56.

3 Hoogendoorn W, van Poppel M, Bongers $P$, et al. Systematic review of psychosocial factors at work and private life as risk factors for back pain Spine 2000;25:2114-25.

4 Kuiper J, Burdorf A, Verbeek J, et al. Epidemiologic evidence on manual materials handling as a risk factor for back disorders: a systematic review. Int J Ind Ergon 1999;24:389-404.

5 Waddell G, Burton A. Occupational health guidelines for the management of low back pain at work: evidence review. Occup Med 2001:51:124-35.

6 Van der Beek AJ, Frings-Dresen MHW. Assessment of mechanical exposure in ergonomic epidemiology. Occup Environ Med 1998;55:291-9.

7 Keyserling W. Workplace risk factors and occupational musculoskeletal disorders, part 1: a review of biomechanical and psychophysical research on risk factors associated with low-back pain. AlHAJ 2000;61:39-50.

8 Adams M, Dolan P. Recent advances in lumbar spinal mechanics and their clinical significance. Clin Biomech 1995;10:3-19.

9 Adams M, Dolan P. Could sudden increases in physical activity cause degeneration of intervertebral discs? Lancet 1997;350:734-5.

10 Risteli J, Risteli L. Assays of type I procollagen domains and collagen fragments: problems to be solved and future trends. Scand J Clin Lab Invest Suppl 1997; XX227:105-13.

11 Langberg H, Skovgaard D, Asp S, et al. Time pattern of exercise-induced changes in type I collagen turnover after prolonged endurance exercise in humans. Calcif Tissue Int 2000;67:41-4.

12 Dupont WD, Plummer WD. Power and sample size calculations: a review and computer program. Controlled Clinical Trials 1990;11:116-28.

13 Hildebrandt VH, Douwes M. Lichamelijke belasting en arbeid: vragenlijst bewegingsapparaat. (Physical load and work: questionnaire on musculoskeletal load and health complaints), Voorburg, Netherlands, Ministerie van Sociale Zaken en Werkgelegenheid, Directoraat Generaal van de Arbeid, 1991.

14 Hildebrandt VH. Prevention of musculoskeletal disorders; setting priorities using the standard Dutch Musculoskeletal Questionnaire. Amsterdam: Vrije Universiteit, 2001.

15 Hildebrandt VH, Bongers PM, van Dijk FJ, et al. Dutch Musculoskeletal Questionnaire: description and basic qualities. Ergonomics 2001;44:1038-55.

16 Rosenquist C, Fledelius C, Christgau S, et al. Serum CrossLaps One Step ELISA. First application of monoclonal antibodies for measurement in serum of bone-related degradation products from C-terminal telopeptides of type I collagen. Clin Chem 1998:44:2281-9.

17 Mouritzen U, Christgau S, Lehmann HJ, et al. Cartilage turnover assessed with a newly developed assay measuring collagen type II degradation products: influence of age, sex, menopause, hormone replacement therapy, and body mass index. Ann Rheum Dis 2003;62:332-6. 
18 MacDonald A, McHenry P, Robins S, et al. Relationship of urinary pyridinium crosslinks to disease extent and activity in osteoarthritis. Br J Rheumatol 1994;33:16-19.

19 Videman T, Gibbons L, Battie $M$, et al. The relative roles of intragenic polymorphisms of the vitamin $D$ receptor gene in lumbar spine degeneration and bone density. Spine $2001 ; 26:$ E7-12.

20 Hutton W, Toribatake $Y$, Elmer W, et al. The effect of compressive force applied to the intervertebral disc in vivo. A study of proteoglycans and collagen. Spine 1998;23:2524-37.

21 Hutton W, Elmer W, Boden S, et al. The effect of hydrostatic pressure on intervertebral disc metabolism. Spine 1999;24:1507-15.

22 Hutton W, Ganey T, Elmer W, et al. Does long-term compressive loading on the intervertebral disc cause degeneration? Spine 2000;25:2993-3004.

23 Kristoffersson A, Hultdin J, Holmlund I, et al. Effects of short-term maximal work on plasma calcium, parathyroid hormone, osteocalcin and biochemical markers of collagen metabolism. Int J Sports Med 1995;16:145-9.

24 Brahm H, Piehl-Aulin K, Liunghall S. Bone metabolism during exercise and recovery: the influence of plasma volume and physical fitness. Calcif Tissue Int 1997;61:192-8.

25 Thorsen K, Kristoffersson A, Hultdin J, et al. Effects of moderate endurance exercise on calcium, parathyroid hormone, and markers of bone metabolism in young women. Calcif Tissue Int 1997;60:16-20.
26 Fujimura R, Ashizawa N, Watanabe $M$, et al. Effect of resistance exercise training on bone formation and resorption in young male subjects assessed by biomarkers of bone metabolism. J Bone Min Res 1997; 12:656-62.

27 Brahm H, Piehl-Aulin K, Saltin B, et al. Net fluxes over working thigh of hormones, growth factors and biomarkers of bone metabolism during short lasting dynamic exercise. Calcif Tissue Int 1997;60:175-80.

28 Hupli M, Hurri H, Luoto $S$, et al. Low synthesis rate of type I procollagen is normalized during active back rehabilitation. Spine 1997;22:850-4.

29 Virtanen P, Viitasalo JT, Vuori J, et al. Effect of concentric exercise on serum muscle and collagen markers Effect of concentric exercise on serum muscle and collagen markers. J Appl Physiol 1993;75:1272-7.

30 Langberg H, Skovgaard D, Petersen L, et al. Type I collagen synthesis and degradation in peritendinous tissue after exercise determined by microdialysis in humans. J Physiol 1999;521(pt 1):299-306.

31 Christgau S, Bitsch-Jensen O, Bjarnason N, et al. Serum CrossLaps for monitoring the response in individuals undergoing antiresorptive therapy. Bone 2000;26:505-11.

32 De Leo V. Ditto A, la Marca A, et al. Bone mineral density and biochemical markers of bone turnover in peri- and postmenopausal women. Calcif Tissue Int 2000;66:263-7.

33 Alvarez L, Peris P, Pons F, et al. Relationship between biochemical markers of bone turnover and bone scintigraphic indices in assessment of Paget's disease activity. Arthritis Rheum 1997;40:461-8.

\section{bmjupdates+}

bmjupdates+ is a unique and free alerting service, designed to keep you up to date with the medical literature that is truly important to your practice.

bmjupdates+ will alert you to important new research and will provide you with the best new evidence concerning important advances in health care, tailored to your medical interests and time demands.

Where does the information come from?

bmjupdates+ applies an expert critical appraisal filter to over 100 top medical journals A panel of over 2000 physicians find the few 'must read' studies for each area of clinical interest

Sign up to receive your tailored email alerts, searching access and more...

www.bmjupdates.com 